\title{
Analysis of Longitudinal Profiles along the Eastern Margin of the Qinghai-Tibetan Plateau
}

\author{
Simon J. Aiken*, Gary J. Brierley ${ }^{1}$ \\ 1 School of Environment, the University of Auckland, Auckland 1010, New Zealand \\ *Corresponding author, e-mail: s.aiken@auckland.ac.nz
}

(C) Science Press and Institute of Mountain Hazards and Environment, CAS and Springer-Verlag Berlin Heidelberg 2013

\begin{abstract}
Resulting from the collision of the Eurasian and Indian plates, the Qinghai-Tibetan Plateau is commonly known as the 'roof of the world'. Collectively the Yarlung Tsangpo, $\mathrm{Nu}$, Lancang, Yangtze, Yalong, and Yellow River basins drain the eastern margin of the plateau. In this paper, we utilize Shuttle Radar Topography Mission elevation data to examine morphometric and relief attributes of these basins to reveal insights into tectonic activity and rates of incision. A robust technique using Matlab is proposed to alleviate errors associated with SRTM data in the derivation of river longitudinal profiles. Convex longitudinal profiles are interpreted to be a product of uplift rates that exceed rates of channel incision along the entire margin of the QinghaiTibetan Plateau. Highest relief towards the south reflects extensive fluvial incision. High relief is also prominent along major active faults. Erosion patterns are related to distance from knickpoints. Highest rates of erosion and incision are evident towards the south, with decreasing values towards the north, suggesting a link between tectonic activity and erosion.
\end{abstract}

Keywords: Longitudinal profile; Erosion; Relief; Tectonics; Qinghai-Tibetan Plateau

\section{Introduction}

The rise of the Himalayas and the Qinghai-

Received: 15 November 2012

Accepted: 24 June 2013
Tibetan Plateau (QTP) and subsequent effects upon the global climate has been of the most debated and controversial topics within geoscience during the past two decades (Molnar and England 1990; Raymo and Ruddiman 1992). Our contemporary understanding of tectonic processes that build topography suggests that factors such as heightened local relief, erosion rates and the shape of longitudinal profiles can be diagnostic of tectonic histories or on-going neotectonic activity (Ahnert 1970; Montgomery 1994; Montgomery and Brandon 2002; Whipple et al. 1999). For example, the shielding of the interior of the QTP is achieved despite regionally variable tectonic and drainage network activity, suggesting that active feedback between tectonic processes and erosion preferentially concentrates erosion along the eastern margin of the QTP. This paper examines several topographic and geomorphic phenomena of these river systems, providing a preliminary assessment of how major river networks that drain the eastern margin of the QTP reflect changes in tectonic history and incision. We compare the results of our analysis with ${ }^{10} \mathrm{Be}$ erosion rates derived by Henck et al. (2010).

Analysis of longitudinal river profiles was first undertaken by Domenico Gugliemini over 300 years ago, predating many related concepts such as the Davisian 'geomorphic cycle' or Playfair's 'law of accordant junctions'. As one of the primary mechanisms by which landscapes manifest and express changes in external boundary conditions, 
longitudinal profiles allow us to determine if channel incision exceeds, equals or is less than the influx of material into the drainage basin (Bishop 2007). Traditionally, this has been achieved by classifying longitudinal profiles as either upwardly concave or convex (Tippet and Hovius 2000). Generally, the configuration of longitudinal profiles varies significantly across and within mountain ranges, with the relative length of the low gradient downstream segment being one of the most important expressions of longitudinal profile variance (Tippet and Hovius 2000). Rivers can only attain a smooth, upwardly concave profile when prevailing catchment and channel characteristics promote the removal of uplifting bedrock at rates that equal or exceed uplift (Hack 1957). When river incision equals the rate of rock uplift the profile effectively remains in steady state equilibrium. If rates of uplift are exceeded by river incision, the profile configuration effectively lowers through time. The decrease in channel gradient as a consequence of profile lowering will cease when slope-discharge relationships are coupled to effectively transport material delivered from upstream reaches. Further upstream, incision of the channel bed continues, resulting in the propagation of the profile form into the mountain belt and elongation of the minimum gradient section (Tippet and Hovius 2000; Burbank et al. 1996b). The opposite of profile elongation occurs when bedrock uplift exceeds incision. Persistence of this imbalance of tectonic input will result in the steepening of the profile and shortening of the minimum gradient downstream segments and increased channel convexity. This simple observation allows differences in profile shape to be interpreted in terms of the balance between rock uplift and fluvial incision (Tippet and Hovius 2000).

The two primary approaches for modelling fluvial erosion are (1) the extrapolation of statistical models and (2) modelling of river processes directly. Because of their reliance on extrapolation, statistical models have been applied to large areas of the earth using a geographic information system (GIS) environment (Ludwig and Probst, 1998; Walling and Webb, 1996). However, neither approach is without limitations. In the case of statistical models the relationship between physical factors and sediment yield (erosion) is constrained because analysis is scale and context dependent. In the case of physical models the complexity of streambed processes is grossly simplified (Finlayson and Montgomery 2003).

Variants of the stream power model have become increasingly common for large scale erosion modelling because they can be readily applied over large areas without the need for detailed knowledge of stream conditions (Finlayson and Montgomery 2003; Jain et al. 2006; 2008). The stream power law of erosion is expressed as:

$$
\dot{\varepsilon}=k A^{m} S^{n}
$$

where $\dot{\mathcal{E}}$ is the incision rate, $A$ is drainage area, $S$ is slope and $k, m$ and $n$ are constants. This law states that in theory the river incision rate is proportional to the product of drainage area and slope. In essence, this means that the larger the river (or upstream drainage area) and the greater the slope, the more erosion can occur. The constants $\mathrm{m}$ and $\mathrm{n}$ moderate the relative importance of drainage area and slope. The constant $k$ controls the proportionality between incision rate and the stream power formula. In reality, $k$ is highly dependent upon prevailing catchment conditions (vegetated versus nonvegetated stream margins for example) and streambed characteristics (exposed bedrock or silt for example) and needs to be measured in the field for each landscape. However, if the goal is to only identify locations or regions in the landscape where erosive potential is highest or most likely to occur, $\mathrm{k}$ is no longer needed and the equation can be rewritten as follows (using $\mathrm{m}$ and $\mathrm{n}$ values for a shear-stress based model):

$$
\frac{\dot{\varepsilon}}{k}=A^{0.5} S^{0.67}
$$

Relief maps can be used to examine landscape dissection or areas of increased erosion. As with all statistics or measures associated with morphometric parameters, relief is dependent upon scale. Therefore, meaningfully determining the appropriate scale to undertake relief analysis is difficult because relief has been shown to possibly be a self-affine fractal (i.e. it is dependent on the scale or window size (Ahnert 1984; Weissel et al. 1994). Despite these limitations, potential differences and meaningful comparisons between 
regions can be completed provided the sampling size window is kept constant for all regions. In this study we use a $5 \mathrm{~km}^{2}$ window, as this scale of analysis has been used successfully in other studies (e.g., Sobet et al. 2003).

\section{Regional Setting}

The Himalayan-Tibetan orogeny was created by the collision of the Indian and Eurasian continental plates 7 70-50 Ma BP (Molnar and Tapponnier 1975). Subsequent crustal shortening $(\sim 1,400 \mathrm{~km})$ led to the development of the Cenozoic Tibetan Plateau sometime in the Eocene. This vast elevated plateau stretches over $1,000 \mathrm{~km}$ from north to south and $2,500 \mathrm{~km}$ from east to west. It is the largest elevated region on the planet, with the average elevation exceeding 3,500 $\mathrm{m}$ a.s.l. Geographically the eastern margin of the QTP (latitude: 31.512; longitude: 96.581) can be defined by the roughly parallel drainages of the $\mathrm{Nu}$, Lancang, Yangtze and Yalong Rivers to the southeast, which collectively form the Three Rivers Region (TRR), the Yarlung Tsangpo to the south and the Yellow River basin to the northeast (Figure 1).

The great orogenic bend that defines the tectonic setting of the south eastern margin of the QTP delineates the transition between east-west trending thrusts of the Himalaya and right-lateral strike slip structures that accommodate the northward motion of the Indian plate relative to China (Burg et al. 1997; Henck et al. 2011). Ongoing collision of the Indian and Eurasian plates since the early Cenozoic has resulted in pronounced deformation and warping of structural fabrics, and topography, with marked variability in plate velocity vectors (Hallet and Molnar 2001; Royden et al. 1997; Sol et al. 2007; Tapponnier et al. 2001; Zhang et al. 2004). Rotation is clearly evident in modern GPS data (Zhang et al. 2004). Large areas of Indochina are being extruded to the south through various shear zones (see Akciz et al. 2008; Gilley et al. 2003; Harrison et al. 1992; Lacassin et al. 1996; Leloup and Kienast 1993; Leloup et al. 1995, 2001; Scharer et al. 1990). This tectonic shear zone characterizes the middle reaches of the TRR.

Much of the pioneering tectonic geomorphic research in this region was stimulated by the fact that a significant component of the Indian and Eurasian plate motion was accommodated by lateral displacement along major-strike faults (Tapponnier and Molnar 1976). Long-term offsets

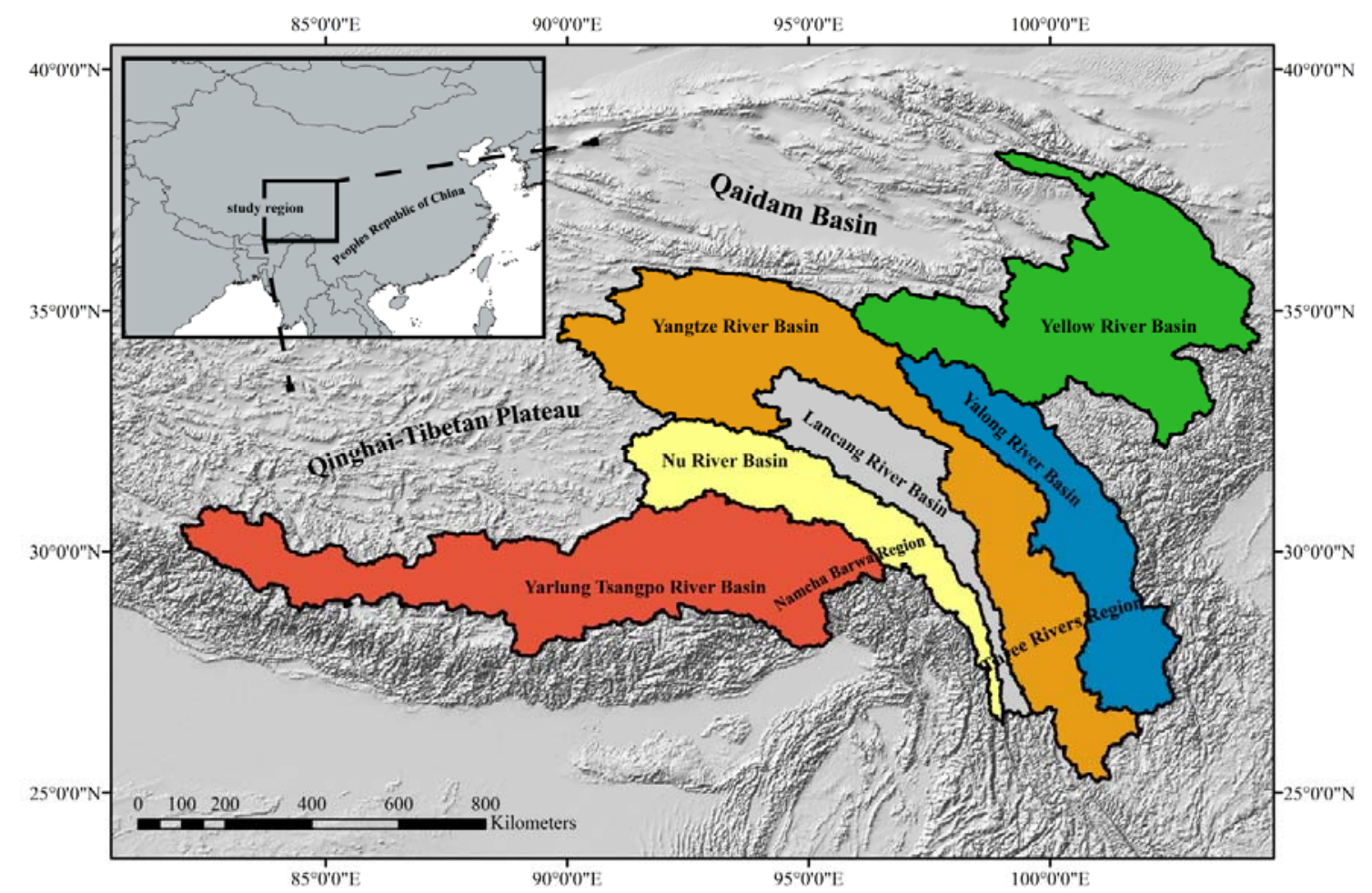

Figure 1 Major drainage basins along the eastern margin of the Qinghai-Tibetan Plateau 
on these faults vary and typically average between 1-20 $\mathrm{mm} \mathrm{yr}^{-1}$ (Tapponnier et al. 2001). Much of the low-relief internally drained plateau interior directly reflects the development of these fault systems. Regardless of this realization, the relative role of transport of material along major strike-slip faults orthogonal to the converge vector between India and Eurasia versus thickening of the Eurasian crust to accommodate convergence is vigorously debated (Molnar and Tapponnier 1975; Tapponnier and Molnar 1977). Despite the major importance regarding the timing and rate of plateau development, there is minimal direct evidence to suggest exactly how rapidly uplift of the QTP occurred (Molnar et al. 1993). Current estimates for when the QTP reached its current elevation are based on inferences regarding the initiation age of east-west extension in central and southern Tibet (Coleman and Hodges 1995; Harrison et al. 1992) or potassic volcanism in north central Tibet (Hacker et al. 2000) sometime during the early Miocene ( 23 Ma BP). Regardless of the conceptually compelling nature of these geodynamic models, a temporal and genetic link between structural extension, volcanism and uplift is yet to be thoroughly demonstrated (Kirby et al. 2002).

Rather than envisioning plateau uplift as a spatially and temporally uniform event, another class of models holds that the plateau grew in lateral extent (primarily to the east) with continuing convergence between India and Eurasia (England and Houseman 1986; Royden 1996; Tapponier et al. 2001). The deformational history of the Qaidam-Qilian Shan region of Qinghai Province seems to support the inference that shortening and crustal thickening has stepped northward with time (Meyer et al. 1998).

Active structures in the TRR (Figure 2) include the Ganzi Fault system (a left-slip strike-slip system in the northern Yangtze watershed), a series of normal faults in the upper Yangtze basin, and

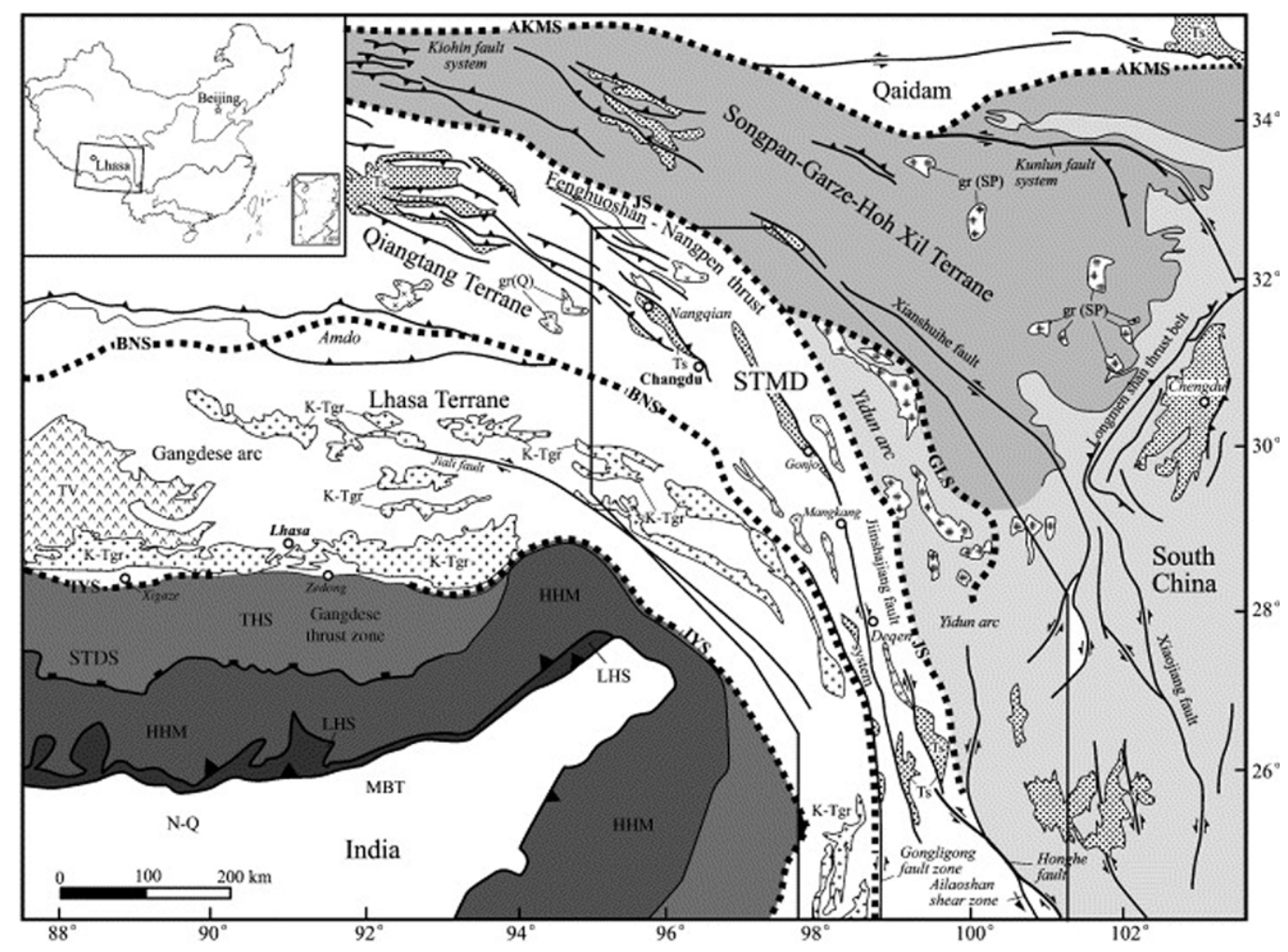

Figure 2 Simplified tectonic map of the Himalayan-Tibetan Orogen (after Yin and Harrison, 200o)

Notes: (1) Major rock and tectonic units: N-Q-Late Tertiary-Quaternary sediments; Ts-Tertiary sedimentary rocks; Tv-Early Tertiary volcanic rocks in Lahsa terrane; THS-Tethyan Himalayan sequences; HHM-High Himalayan metamorphic rocks; LHSLow-Himalayan meta-sedimentary sequence; (2) Major plutons: K-Tgr- Gangdese granite batholith; gr(Q)-Miocene plutons in Qiangtang terrane; gr (sp)-Miocene plutons in Songpan-Ganze-Hoh Xil terrane; gr (YD) -Late Triassic plutons in Yidun arc; (3) Major suture zones: IYS-Indian river-Yalu-Zangbo suture zone; BNS-Bangonghu-Nujiang suture zone; JS-Jinshajiang suture zone; AKMS-Animaqing-Kunlun-Muzitage suture zone; GLS-Ganze-Litang suture zone; (4) Major Cenozoic Structures: STDSSouth Tibetan detachment system; MCT-Main central thrust fault; MBT-Main boundary thrust fault. Figure from Hou et al. (2007) 
some small normal and left-slip faults in the eastern lower-Yangtze (Taylor and Yin 2009). The most active fault in the TRR is the north-striking Ganzi Fault system, which high resolution global position satellite (GPS) data have shown to have significant modern left-slip motion (Taylor and Yin 2009). Thus little extensive active faulting is identified in the region, with the exception of the major strike- slip faults in the upper and eastern Yangtze watersheds, which would be unlikely to dominate regional erosion patterns. Further to the north the Kunlun fault is a significant structural fault that is believed to have been active for the past 40,000 years, resulting in a cumulative offset of more than $400 \mathrm{~m}$ (Klinger et al. 2005). More broadly ongoing deformation of the QTP is concomitant with the ongoing northward migration of the Indian continental plate. Current rates of surface uplift are estimated to be around $10 \mathrm{~mm} \mathrm{yr}^{-1}$ (Lehmkuhl and Owen 2005), yet the overall growth of the QTP is significantly less than this owing to high denudation rates.

At the broadest scale, basement rocks in the TRR and eastern margin of the QTP are comprised of a collage of tectonostratigraphic blocks that were added successively to the Eurasian plate during the Paleozoic and Mesozoic eras. From north to south, the main Tibetan crustal blocks are the Kunlun, Songpan- Garze-Hoh Xil, Qiangtang, and Lhasa terranes (Figure 2). The age of each block decreases southward. All these blocks are characterized by fold and thrust belts that are spatially associated with Tertiary foreland basin development (Yin and Harrison 2000).

Climatically the QTP can be described as a high-altitude semi-arid steppe. Annual precipitation ranges from 100 to $500 \mathrm{~mm} \mathrm{yr}^{-1}$ and falls as a combination of rain, hail and snow. The southern and eastern edges of the QTP support grasslands although permafrost occurs over extensive parts of the plateau. The plateau becomes progressively higher, colder and drier towards the northwest.

Modelling of erosion potential is based primarily on the premise that processes responsible for erosion are enhanced as potential energy inputs into the system increase (e.g., precipitation, hillslope angle or river steepness). In this paper, we explore spatial patterns and relationships between estimated erosion rates and the relief/longitudinal profile of rivers across the eastern margin of the QTP. Previous work on erosion rates inferred from ${ }^{10} \mathrm{Be}$ analysis indicate erosion rates of 1-4 $\mathrm{mm} \mathrm{yr}^{-1}$ in the Namche Barwa region and 0.14-0.58 $\mathrm{mm} \mathrm{yr}^{-1}$ for incised regions east of the TRR (see Figure 2; Booth et al. 2004; Burg et al. 1997; Ding et al. 2001; Finnegan et al. 2008; Malloy 2004; Ouimet et al. 2009; Reid et al. 2005; Seward and Burg 2008; Stewart et al. 2008). Exhumation rates indicate that parts the eastern margin of the QTP have been as high as $10 \mathrm{~mm} \mathrm{yr}^{-1}$ for at least the last 1 to 10 Ma (Arne et al. 1997; Clark et al. 2005b; Enkelmann et al. 2006; Godard et al. 2009; Kamp 2000; Kirby et al. 2002). Towards the east of the TRR, exhumation rates derived from biotite ${ }^{\circ 0} \mathrm{Ar} / 39 \mathrm{Ar}$, apatite and zircon $\mathrm{U}-\mathrm{Th} / \mathrm{He}$, and apatite fission track thermochronometry for incised regions indicate rates of 0.25 and $0.65 \mathrm{~mm} \mathrm{yr}^{-1}$ since 9-13 Ma (Henck et al. 2011). Collectively the geospatial pattern of erosion decreases from west to east. This is considered to represent a decrease in uplift. Further, this also suggests that millennial erosion rates in eastern Tibet broadly reflect local longerterm exhumation rates.

\section{Methodology}

The widespread availability of digital elevations models (DEMs) has revolutionized analytical techniques and practices in geomorphology (e.g. Church 2010). Alongside increasingly powerful personal computers and software, the extraction of catchment and stream network attributes is becoming an increasingly simple task. Unfortunately the quality of the underlying data limits the reliability of DEMs. This statement is especially true in mountainous areas or regions of high topographic relief where steep valley margins and deeply incised river valleys obstruct accurate data acquisition. For example, along the eastern margin of the QTP elevations extend above $5,000 \mathrm{~m}$ with relief greater than $2,500 \mathrm{~m}$. This makes the extraction of accurate attributes difficult and the results are often less than satisfactory. The nature of these errors makes correction prior to extraction difficult. This section outlines a methodology to prepare and extract useable longitudinal river profiles for this region, 
demonstrating how SRTM data can be used for relief and erosion modelling. This approach is applied to six rivers (Yarlung Tsangpo, $\mathrm{Nu}$, Lancang, Yangzte, Yalong and Yellow River Basins) to extract tectonic information regarding the evolution of the QTP.

V-3 SRTM DEM data relevant to the area of interest were downloaded from the Global Land Cover Facility (http://glcf.umiacs.umd.edu/) and imported into ArcGIS 10.1 for hydrologic processing. Using the Archydro extension (http://www.crwr.utexas.edu/giswr/hydro/index.h tml), the raw DEM was screened and processed for areas of internal drainage. Using the screened DEM, the ArcGIS D8 flow direction algorithm was used to determine the direction of steepest downward descent. Flow accumulation grids based on the direction of flow of each cell were also created. Pour points where then used to determine the upstream drainage area. Using these steps, major stream lines were identified at the catchment scale.

Using the ArcGIS 10.1 spatial statistics toolbox, maximum and minimum elevations were identified for an area of $5 \times 5 \mathrm{~km}$. The minimum elevation was then subtracted from the highest elevation to create in new raster showing relief at a scale of 5 $\mathrm{km}^{2}$. Erosion modelling was also completed in ArcGIS using the geoprocessing toolbox and spatial analyst math functions to implement the shear stress based model equation discussed previously. Methodological procedures are summarized in Figure 3 .

Mathworks Matlab is a powerful, high-level computing environment which can be used to filter and smooth erroneous values and anomalies that have been revealed during the extraction process. While other processing environments (e.g. Microsoft Excel or IBM SPSS) offer a variety of other smoothing functions like moving averages, polynomnial curve fitting or spline interpolation, these options are commonly inadequate at removing 'bad' data points and preserving the 'good'. The techniques developed here are by no means the only option for dealing with errors in longitudinal profile data; however they are relatively simple and they provide a good compromise between computational intensity, ease of use and outcome. The Curve Fitting Toolbox ${ }^{\mathrm{TM}}$ provides a variety of different functions associated with data analysis, pre and post screening of data and specifically nonparametric modelling techniques, such as splines, interpolation and smoothing. While other smoother functions, such as moving averages, can also be used, the problem with removing spikes in longitudinal profiles using moving averages is one of information preservation. If the span (or averaging window) is too small, spikes remain, but if the window is too large important geomorphic data are averaged out alongside the spikes - ultimately changing the shape of the longitudinal profile from its fundamental form (Reinfelds et al. 2004; Jain et al. 2006; 2008). Local regression, with and without weights and robustness (lowess, leoss, rlowess and rloess) can also be utilized. The names "lowess" and "loess" are derived from the term "locally weighted

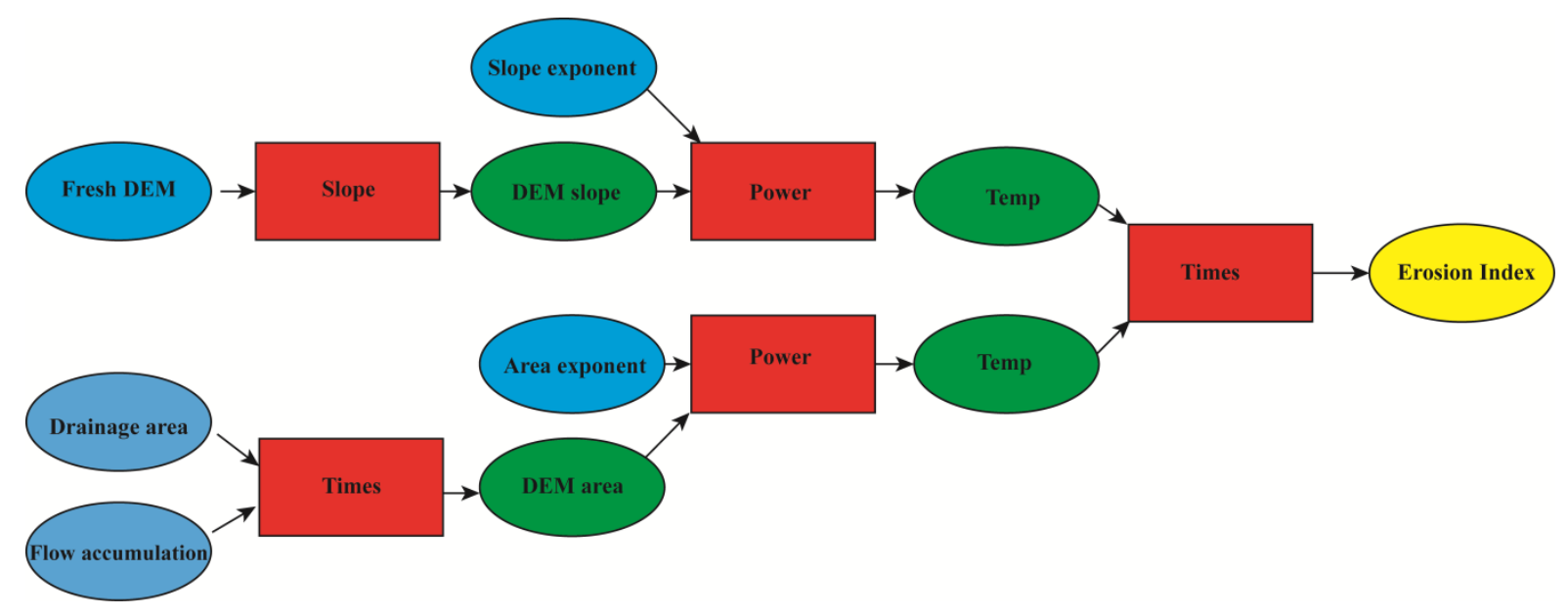

Figure 3 Schematic representation of the steps applied to build an erosion model in ArcGIS. Oval blocks are inputs whereas square blocks are processes. The model flows from left to right and uses both elevation data and drainage area rasters. 
smooth scatter plot," as both methods use locally weighted linear regression to smooth data.

The smoothing process is considered local because, like the moving average method, each smoothed value is determined by the neighbouring points defined within the data span. In addition to the regression weight function, a robust weight function which makes the process resistant to outliers can be used. Finally, the methods are differentiated by the model used in the regression: lowess uses a linear polynomial, while loess uses a quadratic polynomial. When outliers are present, the smoothed values can become distorted thereby failing to reflect the behaviour of the bulk of the neighbouring data points. To overcome this problem, data should be smoothed using a robust procedure that is not influenced by a small fraction of outliers.

The above technique is ideal because the outlier values, in this case elevation spikes, are effectively removed while retaining the shape of the longitudinal, including major breaks in slope and

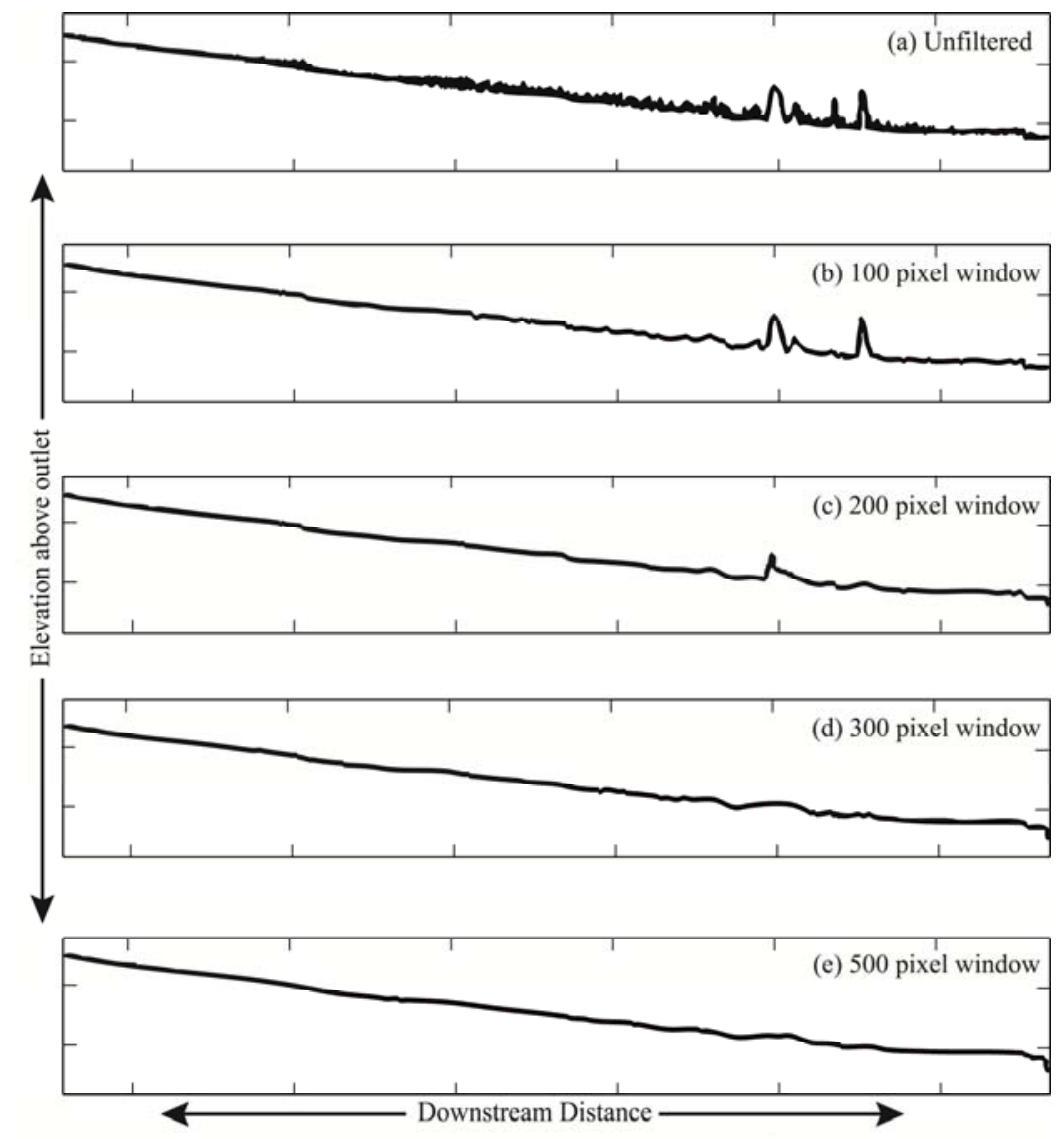

Figure 4 An example of the varying degree and effectiveness of Matlab based smoothing. A window size of 300 represents the best balance between information preservation and smoothing effectiveness. knickpoints. Figure 4 compares the effect of different sized windows. Based upon this graphic, a 300 window size (approximately a $9 \mathrm{~km}$ stream reach) was chosen and the 'rlowess' filter was used to extract longitudinal profile data.

\section{Results}

Relief variability in catchments at the eastern margin of the QTP is shown on Figure 5 . Immediately evident are the elongate, deeply dissected (west-east aligned) landscapes and riverscapes of the Yarlung Tsangpo basin, with extreme relief at the plateau edge, similar extents of dissection in the TRR (with variable areas of limited relief in the upper parts of these catchments), and the dissected trunk stream of the Upper Yellow River adjacent to the plateau margin (and variable relief in upland areas associated with the pattern of basin fills). In summary terms, total relief is most pronounced in the lower reaches of the Yarlung Tsangpo, Lancang, Nu, Yalong and Yangtze River basins, while the upland regions of these catchments located in the interior of the QTP have significantly lower relief. As it drains the base of the Himalayas, the Yarlung Tsangpo has significant relief throughout its entire basin. In contrast, the Yellow River has the most spatially variable distribution of relief, with significant areas of moderate relief reflects the history of basin infilling and incision.

These spatial patterns of topographic variability create stark contrasts in relative erosion potential for basins at the eastern margin of the QTP (Figure 6). Several factors influence the rate and amount of erosion in any landscape. Our simplified model (Equation 2) largely relies upon upstream drainage area and slope. As such, heightened rates of erosion are associated with downstream distance (a proxy for upstream area) and regions of high relief. Based on 


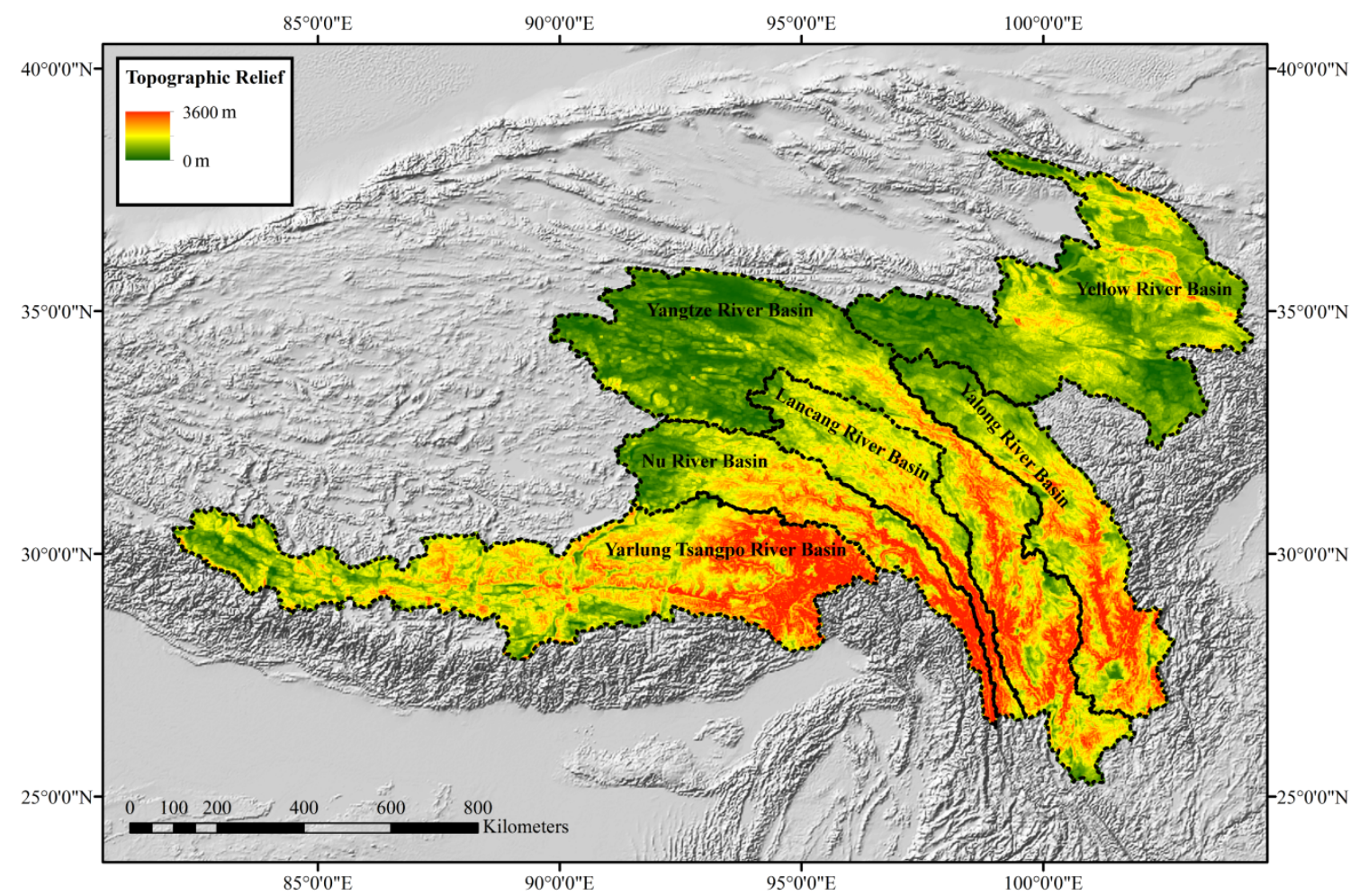

Figure 5 Relief variability at the margins of the Qinghai-Tibetan Plateau. Relief was measured using a $5 \times 5 \mathrm{~km}$ grid. Highest values are found in the southeast along major trunk channels

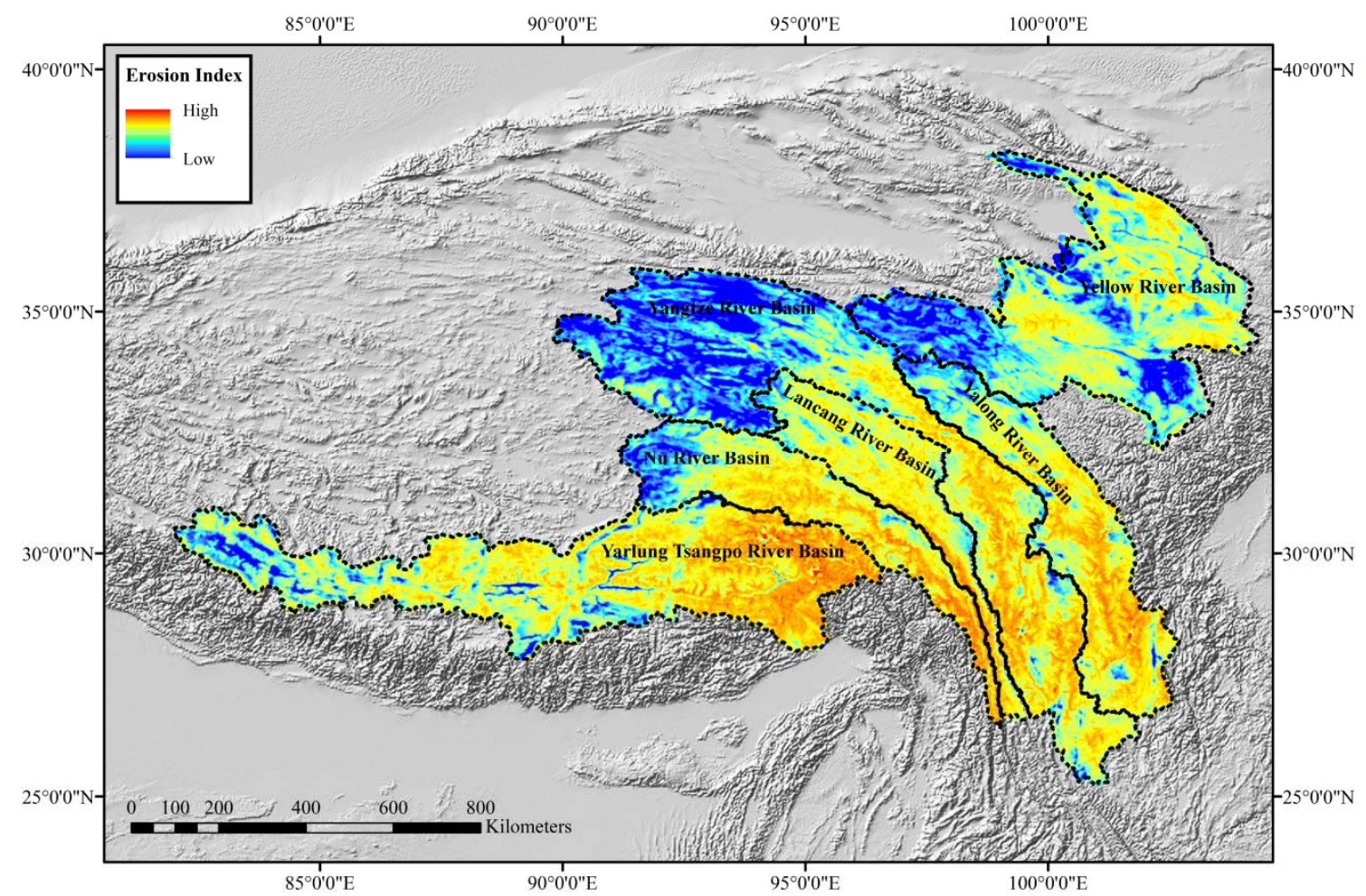

Figure 6 Erosion index modeling at the margins of the QTP. Note how basin erosion potential is much more spatially variable in the Yellow River Basin. This reflects multiple interlinked basins and intervening bedrock ranges that act as local baselevels (see Nicoll et al., in press). Highest rates of erosion for the eastern QTP are found along major stream channels where structural faulting and high relief focus erosional potential. Lowest erosion is found towards the interior of the plateau where drainage area and slope angles are the lowest 
these attributes, erosion is accentuated along the eastern margin of the QTP. In particular, the trunk streams of Yarlung Tsangpo, Lancang, Nu, Yalong and Yangtze River basins have extremely high erosion potential at the plateau margin. The Yellow River has a similar pattern, but the downstream transition is not as pronounced compared with the other basins, with regions of high erosion bracketed by regions of low erosion. Our results show increases in modelled erosion rates and local relief from north to south across the eastern margin of the QTP. These modelled erosion rates parallel changes in previously published datasets,
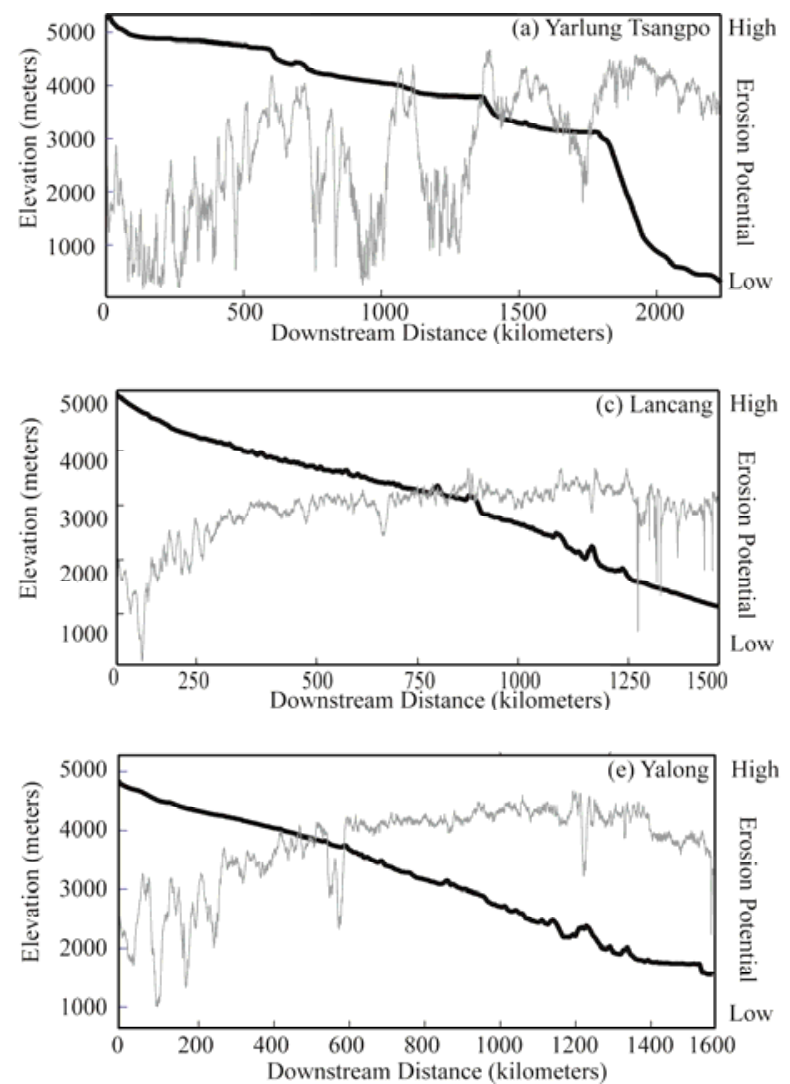

highlighting the importance of changes in rock uplift and structural geologic changes as determinants of erosion rates.

Although the causative factors associated with the production and maintenance of topography for these basins are variable, patterns of relief largely reflect the amount and extent of fluvial incision. All major rivers draining the eastern margin of the QTP have features traditionally associated with high rates of ongoing tectonic activity. Upwardly convex longitudinal profiles suggest that channel incision is unable to match continued uplift (Figure 7). In addition to the broad differences in longitudinal
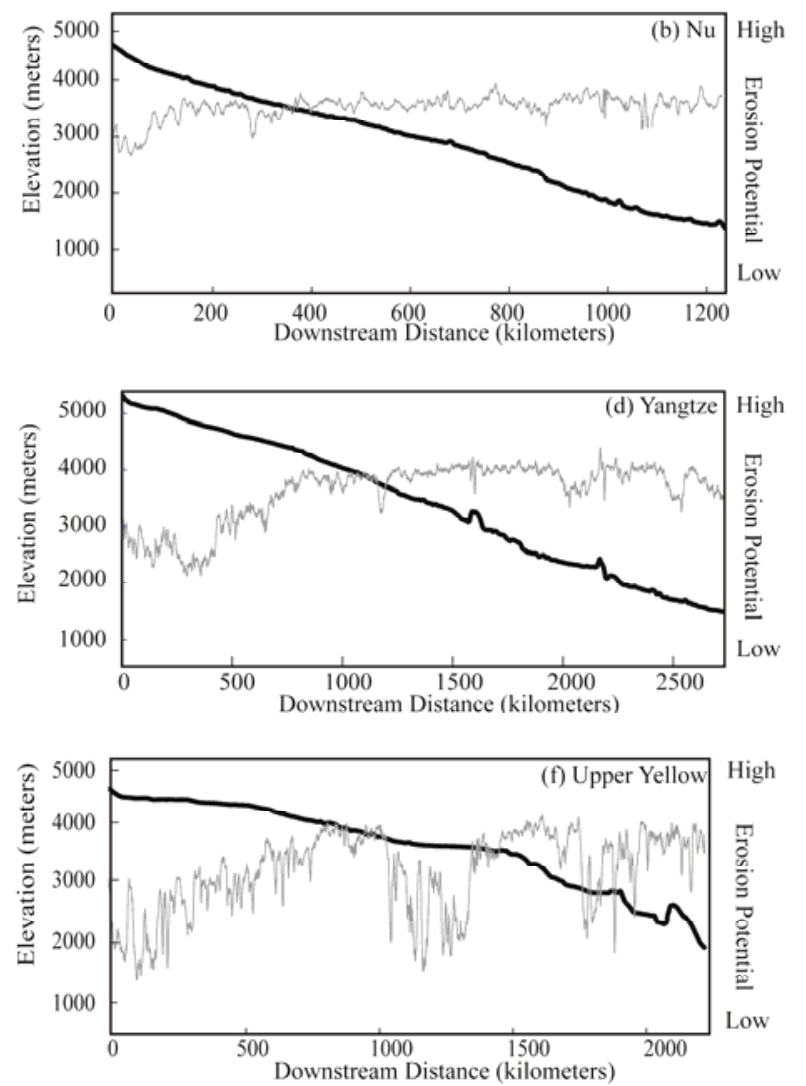

Figure 7 Longitudinal profile of the rivers (a) Yarlung Tsangpo River. The most prominent feature of the profile is the bulging appearance seen throughout the profile alongside the major knickpoints. Potential erosion fluctuates in relation to changes in slope and increasing drainage area, although no clear pattern is evident. (b) Nu River. A minor knickpoint is evident approximately $900 \mathrm{~km}$ downstream. This stream course follows a major structural fault at the eastern margin of the QTP. Erosion potential is remarkably constant along the profile. While not as prominent as the Yarlung Tsangpo River bulge the configuration of the longitudinal is still upwardly convex. (c) Lancang River. This stream course follows a major structural fault at the eastern margin of the QTP. While not as prominent as the Yarlung Tsangpo River bulge the configuration of the longitudinal is still upwardly convex. No major changes in erosion potential are evident along the profile. (d) Longitudinal profile of the Yangtze River. Erosion potential steadily increases downstream over the first 1000 $\mathrm{km}$, a function of increasing drainage area and slope. While not as prominent as the Yarlung Tsangpo River bulge the configuration of the longitudinal is still upwardly convex, with the remainder of the profile being relatively smooth. (e) Longitudinal profile of the Yalong River. No discernable knickpoints are present. However, like all the previous longitudinal profiles the configuration of the longitudinal profile is upwardly convex. No major changes in erosion are identifiable apart from a gradual increase downstream over the first $500 \mathrm{~km}$ the beyond which the erosion index is relatively uniform. (f) Longitudinal profile of the Yellow River. Fluctuating potential for erosion is associated with decrease in slope, which correspond with intermontane brains. 
profile shape the key difference between each longitudinal profile is the number and size of knickpoints. The Yarlung Tsangpo has four major knickpoints separating lower gradient reaches (Figure 7a). Notable bulging through its upper and central lengths has been attributed to repeated blockage by glaciation (Korup and Montgomery 2010), localized aridity (Sobel et al. 2003) or local fault offset (Lavé and Avouac 2001). Potential
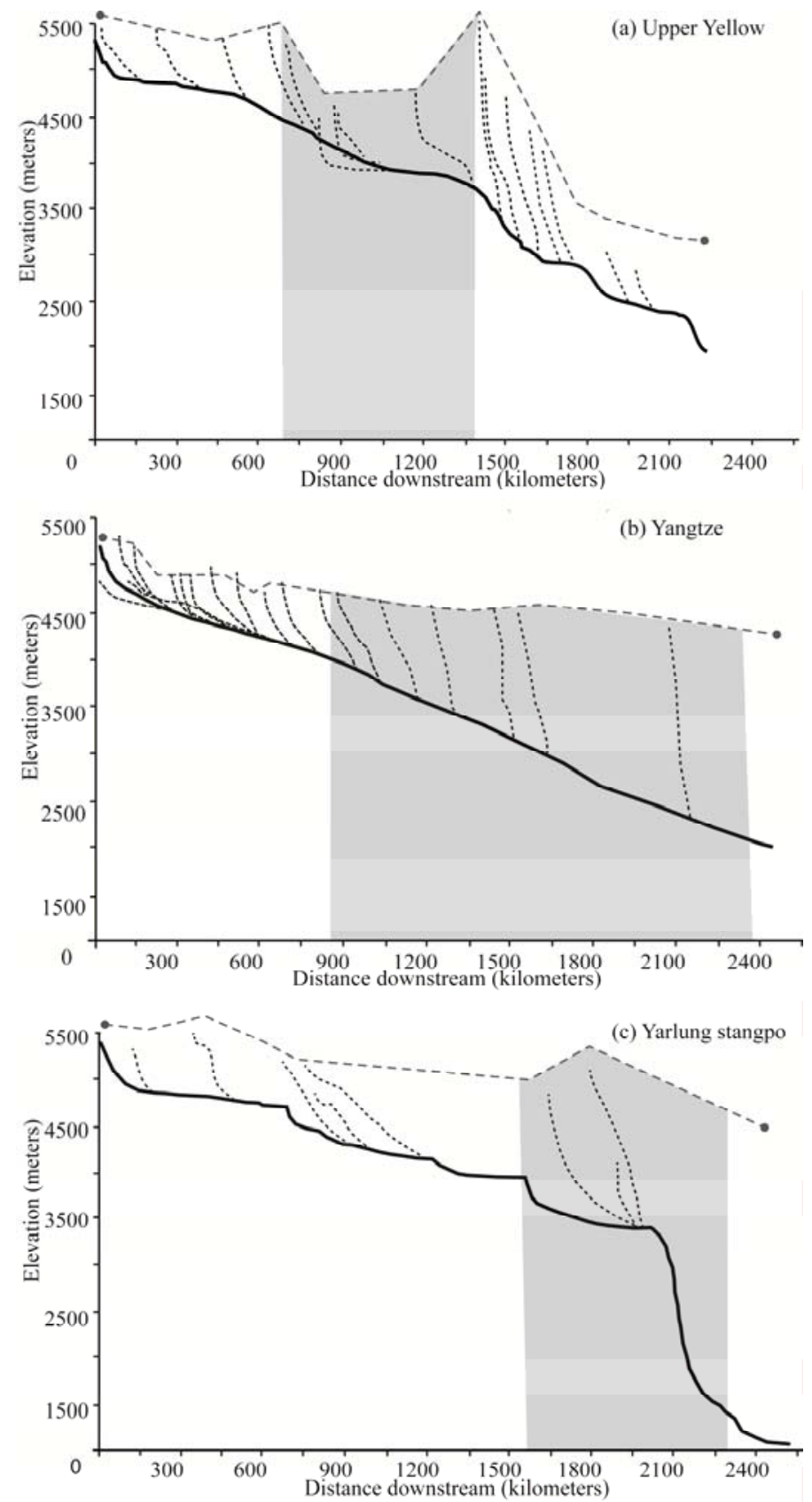

Figure 8 Tributary longitudinal profiles for the Upper Yellow, Yangtze, and Yarlung Tsangpo. Shaded grey areas indicate zones where profiles are significantly different. erosion fluctuates along the longitudinal profile, varying in relation to slope. The longitudinal profiles of the Upper $\mathrm{Nu}$, Lancang, Yangtze and Yalong Rivers are much smoother than that shown for the upper Yarlung Tsangpo, but they also have an upwardly convex shape (Figure $7 \mathrm{~b}-\mathrm{e}$ ). These stream courses follow major structural faults at the eastern margin of the QTP. Only minor breaks of slope are evident for these profiles. Finally, the longitudinal profile of the upper Yellow River has at least four major knickpoints (Figure 7f), but they are generally more gradual and graded than knickpoints shown for the Yarlung Tsangpo (Figure 7a). In this instance the origin of the knickpoints is arguably better understood, as it relates to the history of basin excavation and drainage integration during the Quaternary (Craddock et al. 2010). Interesting insights into patterns of incision and relief development in response to tectonic uplift are gained through analysis of the longitudinal profile forms of tributary systems relative to the trunk stream. These relationships are shown for the upper Yarlung Tsangpo, Yangtze and Yellow Rivers in Figure 8. Tributary longitudinal profiles of the Yangtze River demonstrate a systematic downstream trend in tributary channel profile shapes (Figure 8b). Over steepening of channels adjacent to the margin of the QTP is evident, while tributaries located further towards the interior of the QTP have a more relaxed form. Moderately sloping tributaries are located progressively further from the margin of the QTP. This is consistent with a general downstream trend in increasing tributary-trunk relief and spatial patterns of erosion. Localized factors such as spatially heterogeneous distribution of erosional potential or inheritance of glacially influenced longitudinal profiles have resulted in variable long profile forms for tributary systems.

The trunk channel of the upper Yellow River has several well defined knickpoints (Figure 8a). These over steepened reaches separate the individual drainage basins of the upper Yellow River catchment. The distribution and shape of the tributary channel profiles appear to respond to these 
downstream changes in local base level, which in turn determines local tributary-trunk relief. Oversteepened tributary channels are also located along reaches where the upper Yellow River breaches new intermontane basins, while tributary channel profiles within these intermontane basins have different shapes.

The trunk channel of the Yarlung Tsangpo is punctuated by several well defined knickpoints which progressively increase in size downstream (Figure 8c). However, there is no clear relationship between the distribution of these knickpoints and the shape or distribution of the tributary channel profiles. Potential erosion across the catchment is highly variable (Figure 7a). Downstream increases in tributary-trunk channel relief appear to be the dominant control upon tributary channel profile shape, with more relaxed tributary channels found further upstream where tributary-trunk relief is less.

In the discussion, this analysis of spatial variability in relief, relative erosion potential, and the shape of trunk stream and tributary longitudinal profiles for basins at the eastern margins of the QTP is related to our understanding of tectonic controls upon landscape forms in the region.

\section{Discussion}

The stepped growth model of the QTP requires a series of uplifted tectonostratigraphic blocks, separated by eastward striking faults, to transport material away from the main collision zone. The upwardly convex longitudinal profiles of all the major rivers draining the eastern margin of QTP indicate that rates of channel incision are outpaced by tectonic forcing. This is consistent with this tectonic model. Several important implications can be drawn from this. Findings suggest that the affected drainage basins, particularly the $\mathrm{Nu}$, Lancang, Yangtze and Yalong basins are in a state of topographic flux (i.e., non-equilibrium). This result parallels the configuration of longitudinal profiles draining the Himalayan Arc (Seeber and Gornitz 1983), reflecting active uplift of both the southern and eastern margins of the QTP. The Nu, Lancang, Yangtze and Yalong river basins have similar longitudinal profiles with near-consistent gradients throughout (Figure 7). Major knickpoints or breaks in slope are uncommon (when compared to either the Yarlung Tsangpo or Yellow River). A possible reason for this configuration is that all rivers drain large, flat upland areas with trunk streams controlled by geologic faulting, thereby focusing incision along narrow corridors. Such coupling between incision and tectonic is seen in other orogens around the world (e.g. Taiwan, South Island of New Zealand). Similar patterns, where heightened rates of incision promote increased uplift, have been predicted by numerical modelling (see Beaumont et al. 2000; Willet et al. 2001).

As strike-slip faulting began $15 \mathrm{Ma}$ or less after the onset of collision, and has been ongoing since, it is not possible to determine a single longitudinal profile shape that is diagnostic or serves as a proxy for the age/onset of incision. However, the activation of the large strike-slip faults, which appear to have propagated eastward (Metivier et al. 1998; Meyer et al. 1998), was diachronous, starting earlier in the south than in the north (Gaudemer et al. 1995; Leloup et al. 1995). The age of strongly folded detrital sediments younger than $100 \mathrm{Ma}$ also decreases northward across the plateau (Tapponnier et al. 1990). As uplift has been effectively ongoing for so long, trunk channels are unlikely to register or manifest changes based upon the onset of tectonic activity.

More comprehensive drainage network analysis could prove fruitful in efforts to interpret controls upon river evolution in this area (see Wang et al. 2010). Prior to the existence of the contemporary Yellow River (Late Pliocene - early Pleistocene), it is believed that a series of shallow lakes (thus closed basins) existed along the stream course (Craddock et al. 2010). Headward migration by a fluvial knickpoint integrated these basins into the Yellow River. The discrete baselevels observed along the longitudinal profile are proposed to reflect this wave of incision (Craddock et al. 2010). As tributary-trunk channel relief increases, tributary streams adjust to the new base level.

Comparison of the local erosion index with longitudinal profiles reveals some minor, but discernible changes (Figure 9). These changes were most pronounced in the Yarlung Tsangpo and upper Yellow River longitudinal profiles, where reaches of stable baselevel resulted in decreases in the erosion index. Analysis of the broader regional 

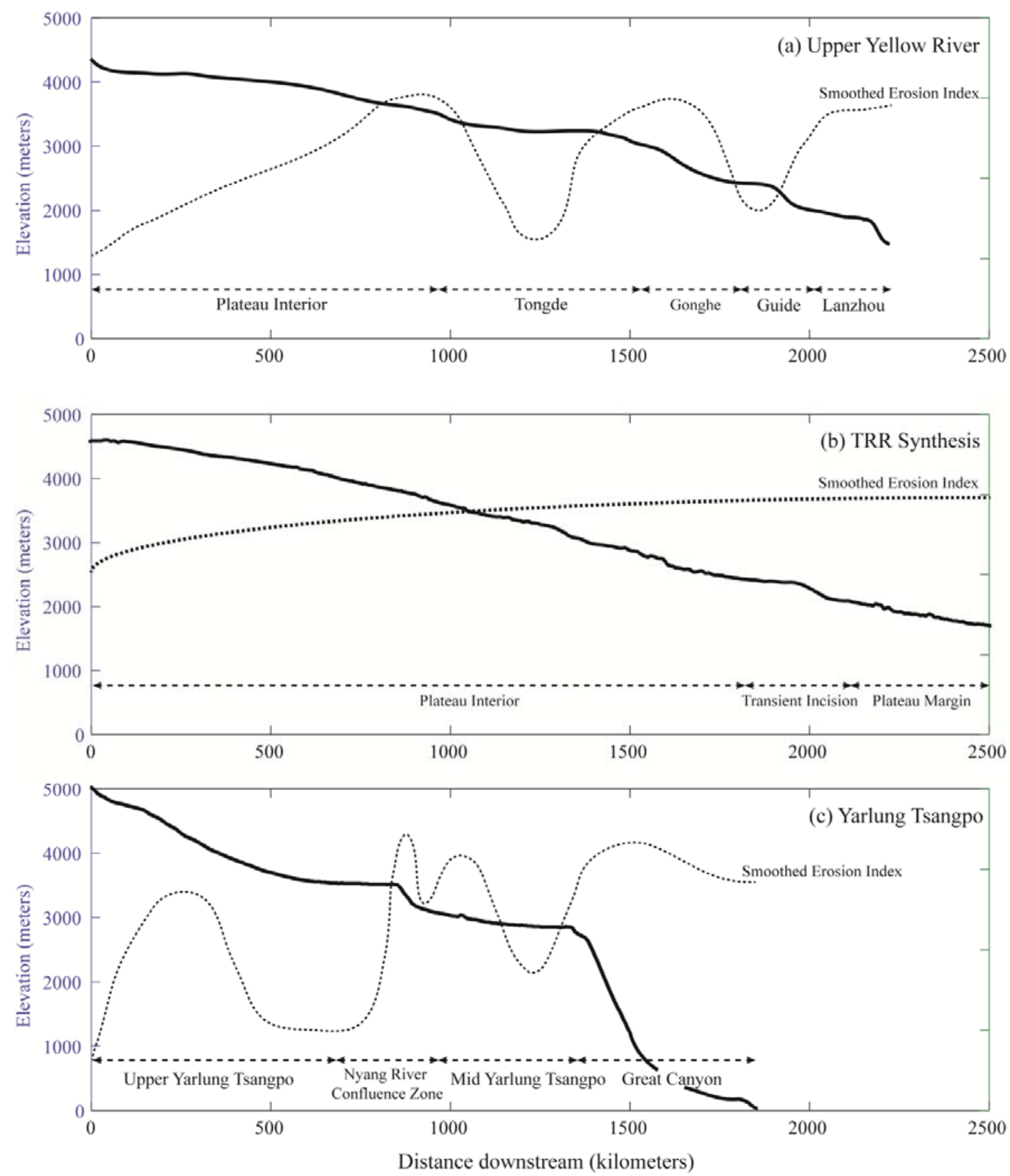

Figure 9 A synthesis of the trunk channel longitudinal profiles and their associated erosion patterns draining the eastern margin of the QTP. Factors determining the location of knickpoints along each profile are regionally specific. However, the general shape of each profile is indicative of pervasive long term uplift outpacing incision. Erosion along these stream courses increases downstream, with local variances reflecting changes in slope and knickpoint distribution.

context indicates that the highest rates of erosion are associated with regions towards the south. In particular the lower reaches of the Yarlung Tsangpo, Nu, Lancang, Yangtze and Yalong Rivers are characterized by extreme relief at the margins of the QTP. Based upon studies elsewhere (Binnie et al. 2007; Harrison 2000; Milliman and Syvitski 1992; Montgomery and Brandon 2002; Summerfield and Hulton 1994), this suggests that landscape attributes such as slope or drainage density dynamically adjust to increased tectonic forcing or impact. These changes could potentially 
manifest themselves as knickpoints that migrate through the channel system.

Highest relief is found towards the south and follows major river courses. High relief is also noticeable along major active faults, e.g. the Red River or Xianshuihe faults (Figure 2). This is indicative of the interplay between surficial erosion and tectonic processes that create and maintain relief. These findings support the stepped model of QTP evolution proposed by Tapponnier et al. (2001) and the findings of Liu-Zeng et al. (2010). The most compelling evidence for this is the southnorth transition in relief and erosion characteristics. It is important to note that our analysis was undertaken at a scale finer than LiuZeng et al. (2008), who used a $10 \times 10 \mathrm{~km}$ moving window to calculate relief, therefore addressing arguments that topography is fractural or selfaffirming in nature. The crude shapes of the profiles support assertions that new crustal material is input into these catchments on a semi regular geologic basis. This may reflect propagation of the eastward striking faults as predicted by the Tapponnier et al. (2001) model. Erosion modelling also strongly suggests a coupling being surficial erosional processes and tectonics, as highest relief values are found towards the south, closest to the collision zone and dense structural faulting.

Lithology exerts a strong control on fluvial incision rates (Stock and Montgomery 1999) and in some cases it may have the same explanatory power as rock uplift rates (Duvall et al. 2004). Prospectively, highly erosion resistant rocks in the west relative to less resistant lithologies in the east may explain changes to erosion rates derived from ${ }^{10} \mathrm{Be}$ analysis. However, closer examination of catchment maps reveals variable underlying bedrock, with only regional scale trends of more deeply exhumed rocks (Figure 2). Erosionally resistant metamorphic rocks are found towards the south southeast while more easily erodible sedimentary rocks are found in the northern area. Therefore, if lithology was the dominant control on erosion rates across the eastern margin of the QTP, the opposite trend would be expected to be seen in ${ }^{10}$ Be erosion rates (Henck et al. 2011).

Also, the role of topography and the relative contribution of both sediment from low-relief surfaces (see Clark et al. 2006; Liu-Zeng et al. 2008) and deeply incised river reaches must be considered as determinants of landscape form. In theory, regions of lesser incision (e.g., the headwater plateau reaches) should have lower basin-wide erosion rates than heavily incised downstream reaches. This pattern is observed in both our modelled erosion rates and measurements derived from ${ }^{10} \mathrm{Be}$ estimates, at least for the southern river basins. However, this pattern is not observed along the upper Yellow River, where modelled rates are much more spatially variable. This pattern may reflect a fundamental difference in the evolutionary trajectory of the upper Yellow River, relative to the other river basins. As the total variance in fluvial incision is relatively minor for the southern basins, the amount and extent of fluvial incision cannot fully account for changes in erosion rates.

Henck et al. (2010) suggest that although precipitation and local relief explain much of the observed variability in erosion rates across the QTP, tectonic setting is the ultimate determinant of erosion rates. Longitudinal profiles analyzed in this study shed further light on this interpretation. Major channel knickpoints are located through reaches at the margins of the QTP, the presence of which drive local and regional shifts in base level. This, in turn, drives increases in relief and fluvial incision. Despite the parallel eastward decrease in exhumation rates (and likely rock uplift) suggesting that less material is available to erode lower stream reaches, this interpretation ignores other incisional mechanics such as sediment storage on the river bed that armour and inhibit further incision (see Kuo and Brierley 2012; Sklar and Dietrich 2001). Alternatively, variability in incision histories and erosion rates may be explained by the presence of various shear zones that fracture bedrock and decrease resistance to erosion. Clearly, these effects are catchment or reach specific, reflecting geographical and historical controls upon any given river system. Recent developments in remotely sensed data, measurement techniques and analytical tools will greatly enhance our capacity to assess the relative contribution of these potential influences upon erosion rates.

\section{Conclusion}

Analysis of longitudinal profiles for the major 
streams draining the eastern margin of the QTP demonstrates that despite their extreme erosion rates, these streams are unable to keep pace with tectonic uplift. Relief and erosion modelling, and the presence of active faults, strongly support the tectonic evolution model and erosion-uplift linkage proposed by Tapponnier et al. (2001), as validated by Zheng et al. (2008) and Liu-Zeng et al. (2010). Further in-depth analyses using higher resolution data, alongside palaeoenvironmental work, will greatly benefit our understanding of geological and climatic controls upon drainage evolution on the QTP.

\section{References}

Ahnert F (1984) Local relief and the height limits of mountain ranges. American Journal of Science 284: 1035-1055. DOI: 10.2475/ajs.284.9.1035

An Z, Kutzbach JE, Prell WL, Porter SC (2001) Evolution of Asian monsoons and phased uplift of the Himalaya-Tibetan plateau since Late Miocene times. Nature 411: 62-66. DOI: 10.1038/35075035

Beaumont C, Kooi H, Willett S (2000) Coupled tectonic-surface process models with applications to rifted margins and collisional orogens. In: Geomorphology and Global Tectonics, Summerfield, M.A (ed.). Wiley, Chichester. p 29

Binnie S, Phillips W, Summerfield M, Fifield L (2007) Tectonic uplift, threshold hillslopes, and denudation rates in a developing mountain range. Geology 35: 743-746. DOI: 10.1130/G23641A.1

Bishop P (2007) Long-term landscape evolution: Linking tectonics and surface processes. Earth Surface Processes and Landforms 32: 329-365. DOI: 10.1002/esp.1493

Burbank D, Leland J, Fielding E, Anderson R, Brozovic N (1996) Bedrock incision, rock uplift and threshold hillslopes in the northwestern Himalayas. Nature 379: 505-510. DOI: $10.1038 / 379505$ ao

Coleman M, Hodges K (1995) Evidence for Tibetan Plateau uplift before $14 \mathrm{Ma}$ ago from a new minimum age for eastwest extension. Nature 374: 45-92. DOI:10.1038/374049ao

Craddock WH, Kirby E, Harkins NH, Zhang H, Shi J (2010) Rapid fluvial incision along the Yellow River during headward basin integration. Nature Geoscience 3: 209-213. DOI: $10.1038 /$ ngeo777

England P, Houseman G (1986) Finite strain calculations of continental deformation II: comparison with the India-Asia collision zone. Journal of Geophysical Research 91: 36643676. DOI: 10.1029/JBo91iBo3po3664

Finlayson DP, Montgomery DR (2003) Modelling large-scale fluvial erosion in geographical information systems. Geomorphology 53: 147-164. DOI: 10.1016/So169-555X(02) o0351-3

Gaudemer Y, Tapponnier P, Meyer B, et al. (1995) Partitioning of crustal slip between linked, active faults in the eastern Qilian Shan, and evidence for a major seismic gap, the Tianzhu gap, on the western Haiyuan Fault, Gansu (China). Geophysical Journal International 120: 599-645. DOI: 10.1111/j.1365-246X.1995.tbo1842.x

Hack J (1957) Studies of longitudinal stream profiles in Virginia and Maryland. US Geological Survey Professional Paper 294:

\section{Acknowledgements}

Funding was provided by International Science \& Technology Cooperation Program of China (Grant Nos. 2011DFG93160, 2011DFA 20820). Gary Brierley gratefully acknowledges support from a Visiting Professorship awarded by the Chinese Academy of Sciences. We thank Heqing HUANG and Xi-lai LI for logistical support that facilitated the completion of this research. Paul Augustinus provided invaluable feedback on an earlier revision of this manuscript. Constructive and insightful comments by reviewers helped to improve this manuscript.

45-97.

Hacker BR, Gnos E, Ratschbacher L, et al. (2000) Hot and dry xenoliths from the lower crust of Tibet. Science 287: 24632466. DOI: $10.1126 /$ science.287.5462.2463

Harrison CG (2000) What factors control mechanical erosion rates? International Journal of Earth Sciences 88: 752-763. DOI: $10.1007 /$ soo5310050303

Harrison TM, Chen W, Leloup PH, et al. (1992) An early Miocene transition in deformation regime within the Red River fault zone, Yunnan, and its significance for the IndoAsian tectonics. Journal of Geophysical Research 97: 71597182. DOI: $10.1029 / 92 J B o 0109$

Hou Z, Zaw K, Pan G, et al. (2007) Sanjiang Tethyan metallogenesis in S.W. China: Tectonic setting, metallogenic epochs and deposit types. Ore Geology Reviews 31: 48-87.

Jain V, Fryirs K, Brierley GJ (2008) Where do floodplains begin? The role of total stream power and longitudinal profile form on floodplain initiation processes. Geological Society of America Bulletin 120: 127-141. DOI: 10.1130/B26092.1

Jain V, Fryirs K, Preston N, et al. (2006) Comparative assessment of three approaches for deriving stream power plots along long profiles in the upper Hunter River catchment, New South Wales, Australia. Geomorphology 74: 297-317. DOI: $10.1130 /$ B26092.1

Kirby E, Reiners PW, Krol MA, et al. (2002) Late Cenozoic evolution of the eastern margin of the Tibetan Plateau: Inferences from ${ }^{40} \mathrm{Ar} / 39 \mathrm{Ar}$ and (U-Th)/He thermochronology. Tectonics 21: 1-20. DOI: 10.1029/2000TCoo1246

Klinger Y, Xu X, Taponnier P, et al. (2005) High-Resolution Satellite Imagery Mapping of the Surface Rupture and Slip Distribution of the Mw $\sim 7.8,14$ November 2001 Kokoxili Earthquake, Kunlun Fault, Northern Tibet, China. Bulletin of the Seismological Society of America 95: 1970-1987. DOI: 10.1785/0120040233

Kuo C, Brierley GJ (2012) The influence of landscape configuration upon patterns of sediment storage in a highly connected river system. Geomorphology 180: 255-266. DOI: 10.1016/j.geomorph.2012.10.015

Lavé J, Avouac J (2001) Fluvial incision and tectonic uplift across the Himalayas of Central Nepal, Journal of Geophysical Research. 106: 26561-26592. DOI: 10.1029/ 2001JB000359

Leloup PH, Harrison TM, Ryerson FJ, et al. (1995) The Ailao Shan-Red River shear zone (Yunnan, China), Tertiary transform boundary of Indochina. Tectonophysics 251: 3-84. 
DOI:10.1016/0040-1951(95)ooo70-4

Liu-Zeng J, Tapponnier P, Gaudemer Y, et al. (2008) Quantifying Landscape Differences Across the Tibetan Plateau: Implications for Topographic Relief. Journal of Geophysical Research 113: 2003-2012. DOI: 10.1029/2007JF 000897

Ludwig W, Probst JL (1998) River sediment discharges to the oceans: present-day controls and global budgets. American Journal of Science 298: 265-295. DOI: 10.2475/ajs.298.4.265

Metivier F, Gaudemer Y, Tapponnier P, et al. (1998) Northeastward growth of the Tibet plateau deduced from balanced reconstruction of two depositional areas: The Qiadam and Hexi Corridor basins, China. Tectonics 17: 823842. DOI: $10.1029 / 98 \mathrm{TC} 2764$

Meyer B, Tapponnier P, Bourjot L, et al. (1998) Crustal thickening in Gansu-Qinghai, lithospheric mantle subduction, and oblique, strike-slip controlled growth of the Tibet plateau. Geophysical Journal International 135: 1-47. DOI: 10.1046/ j.1365-246X.1998.00567.x

Nicoll T, Brierley G, Yu G. In press. A broad overview of landscape diversity of the Yellow River Source Zone. Journal of Geographical Sciences.

Milliman JPM, Syvitski J (1992) Geomorphic/tectonic control of sediment discharge to the ocean - the importance of small mountainous rivers. Journal of Geology 100: 525-544. DOI: 10.1086/629606

Molnar P, Tapponnier P (1977) Relation of the tectonics of eastern China to the India-Eurasia collision: Application of slip-line field theory to large-scale continental tectonics. Geology 5 (4): 212-216. DOI: 212-216. 10.1130/0091-7613

Molnar P, Tapponnier P (1975) Cenozoic tectonics of Asia: Effects of a continental collision. Science 189: 419-426. DOI: 10.1126/science.189.4201.419

Molnar P, England P (1990) Late Cenozoic uplift of mountain ranges and global climate change: chicken or egg? Nature 346 : 29-34. DOI:10.1038/346029ao

Molnar P, England P (1993) Mantle dynamics, the uplift of the Tibetan Plateau, and the Indian monsoon. Reviews of Geophysics 31: 357-396. DOI: 10.1029/93RG02030

Montgomery DR (1994) Valley Incision and the uplift of mountain peaks. Journal of Geophysical Research 99: 1391313921. DOI: 10.1029/94JBoo122

Montgomery DR, Korup O (2010) Preservation of inner gorges through Alpine glaciations. Nature Geoscience 4: 62-67. DOI: 10.1038/ngeo1030

Montgomery DR, Brandon MT (2002) Topographic controls on erosion rates in tectonically active mountain ranges. Earth and Planetary Science Letters201: 481-489. DOI: 10.1016/ so012-821x(02)00725-2

Raymo ME, Ruddiman WF (1992) Tectonic forcing of late Cenozoic climate. Nature 359: 117-122. DOI: 10.1038/ $359117 \mathrm{ao}$
Reinfelds I, Cohen T, Batten P, et al. (2004) Assessment of downstream trends in channel gradient, total and specific stream power: a GIS approach. Geomorphology 60: 403-416. DOI: 10.1016/j.geomorph.2003.10.003

Royden L (1996) Coupling and decoupling of crust and mantle in convergent orogens: Implications for strain partitioning in the crust, Journal of Geophysical Research 101: 17679-17705. DOI: $10.1029 / 96 J B 00951$

Seeber L, Gornitz V (1983) River profiles along the Himalayan Arc as indicators of active tectonics. Tectonophysics 92: 335367. DOI:10.1016/0040-1951(83)90201-9.

Sobel ER, Hilley GE, Strecker MR (2003) Formation of internally drained contractional basins by aridity-limited bedrock incision. Journal of Geophysical Research 108: 23442365. DOI: 10.1029/2002JBo01883

Summerfield MA, Hulton NJ (1994) Natural controls of fluvial denudation rates in major world drainage basins: Journal of Geophysical Research. 99: 13871-13883. DOI: 10.1029/ 94JBoo715

Tapponnier P, Meyer B, Avouac JP, et al. (1990) Active thrusting and folding in the Qilian Shan, and decoupling between upper crust and mantle in northeastern Tibet. Earth and Planetary Science Letters 97: 382-403. DOI: 10.1016/ 0012-821x(90)90053-Z

Tapponnier P, Zhiqin X, Roger F, et al. (2001) Oblique stepwise rise and growth of the Tibet Plateau. Science 294: 1671-1677. DOI: $10.1126 /$ science.105978

Tippett J, Hovius N, (2000) Geodynamic processes in the Southern Alps, New Zealand. In: Geomorphology and Global Tectonics, Summerfield M. A (eds.). Wiley: Chichester. p 109.

Walling DE, Webb BW (1996) Erosion and sediment yield: a global overview. In: Walling DE, Webb BW (eds.), Proceedings of an International Symposium on Erosion and Sediment Yield: Global and Regional Perspectives. International Association of Hydrological Sciences, v. 239. IAHS-Publications, Louvain. p 2.

Wang Z, Yu G, Brierley GJ, et al. (2010) Stream networks and knickpoints in the Sanjiangyuan region. In: Brierley GJ, Li X and Gang C (eds.), Landscape and Environmental Science and Management in the Sanjiangyuan region. Qinghai People's Publishing House, Xining. p 27.

Weissel JL, Pratson F, Malinverno A (1994) The length scaling properties of topography. Journal of Geophysical Research. 99: 13997-14012. DOI: 10.1029/94JBo0130

Whipple K, Kirby E, Brocklehurst S (1999) Geomorphic limits to climatically induced increases in topographic relief. Nature 401: 39-43. DOI: $10.1038 / 43375$

Willet S, Slingerland R, Hovius N (2001) Uplift, shortening and steady state topography in active mountain belts. American Journal of Science 301: 455-485. DOI: 10.2475/ajs.301.45.455 